\title{
Effect Size Test of Learning Model ARIAS and PBL: Concept Mastery of Temperature and Heat on Senior High School Students
}

\author{
Chairul Anwar ${ }^{1 *}$, Antomi Saregar ${ }^{1}$, Yuberti Yuberti ${ }^{1}$, Nova Zellia ${ }^{2}$, Widayanti Widayanti ${ }^{2}$, \\ Rahma Diani ${ }^{1}$, Ismail Suardi Wekke ${ }^{3}$ \\ ${ }^{1}$ State Islamic University Raden Intan Lampung, INDONESIA \\ 2 University of Lampung, INDONESIA \\ ${ }^{3}$ Sekolah Tinggi Agama Islam Negeri Sorong, West Papua, INDONESIA
}

Received 18 August 2018 • Revised 24 October 2018 • Accepted 6 December 2018

\begin{abstract}
The study aims to find out first, whether there is a difference between the learning model of Assurance, Relevance, Interest, Assessment, and Satisfaction (ARIAS) and Problem Based Learning (PBL) on the concept mastery of temperature and heat. Second, it also aims to investigate the effectiveness of ARIAS and PBL learning model on the concept mastery of temperature and heat. The study uses Quasi-Experiment method with Nonequivalent Control Group Design, and sample selection with Cluster Random Sampling technique. This technique consists of two classes, i.e., experimental class I applying ARIAS learning model and experimental class II applying PBL model. The technique of data collection uses test instruments (pretest and posttest). The result of $\mathrm{t}$ test with $5 \%$ significant level indicates that $\mathrm{t}$ calculate $=2.03>\mathrm{t}$ table $=1.99$, thus, it is concluded that (1) there is a difference using the learning model of ARIAS and PBL on concept mastery. The result of Effect Size test is a score of 0.45 with the medium category. Based on the result, it can be concluded that (2) using the learning model of ARIAS is more effective than PBL on the concept mastery of temperature and heat in high school students.
\end{abstract}

Keywords: misconception of physics learning, ARIAS, PBL, concept mastery, the effectiveness of learning

\section{INTRODUCTION}

A major problem encountered in the learning process is that learning in the classroom is still focused on listening and memorizing activities rather than on the interpretation and meaning, as well as building knowledge (Suardani, Swasta, \& Widiyanti, 2014; Taale, 2013; Gambari, Shittu \& Taiwo, 2016; Gorev et al., 2017; Thibaut et al., 2018). One of the efforts to overcome this problem is through learning innovation approach so that learning is more interesting and increases students' learning interest (Aina, 2015; Hanson, 2016; Kurihara, 2016; Suryati, Masrukan, \& Wardono, 2013; Wekke \& Hamid, 2013). A serious effort has been made in the domain of Natural Sciences, especially in the subject of Physics (Piyatissa, Johar \& Tarofder, 2018; Yanga \& Yenb, 2016; Wijayanti, Sukarmin, \& Wiyono, 2015).

Physics is a universal science which underlies the development of modern technology as well as plays an important role in various disciplines and advancement of the human mind (Becerra-Labra, Gras-Martí, \& Martínez Torregrosa, 2012; Garaeva \& Ahmetzyanov, 2018; Gazzola, Otero \& Llanos, 2015; Make \& Yonas, 2018; Purwanti \& Manurung, 2015; Saregar, 2016; Setyorini, Sukiswo, \& Subali, 2011; Luneeva \& Zakirova, 2017; Kalimullin \& Utemov, 2017; Ke, Borakova \& Valiullina, 2017; Cao, Kurbanova \& Salikhova, 2017).

However, learning Physics in a classroom still faces several problems, such as Students' belief that physics is difficult and uninteresting (Basuki, Doyan, \& Harjono, 2015). Besides, the learning methods are still conventional

(c) 2019 by the authors; licensee Modestum Ltd., UK. This article is an open access article distributed under the terms and conditions of the Creative Commons Attribution License (http://creativecommons.org/licenses/by/4.0/). 《chairul.anwar@radenintan.ac.id (*Correspondence) 《antomisaregar@radenintan.ac.id 


\section{Contribution of this paper to the literature}

- ARIAS learning model is more effective compared to Problem-Based learning model in improving the physics concepts understanding

- This study reviews the actual reasons behind the concepts understanding improvement of the ARIAS learning model

such as lecture method (Gok \& Silay, 2008). This causes students to be less excited and get bored (Khoiriyah \& Rusimamto, 2016). Moreover, students also often get only one-way information, without being reinforced in understanding the concept of the ongoing subject material (Jayakumar, 2016; Kweka \& Ndibalema, 2018; Lebdiana, Sulhadi, \& Hindarto, 2013).

Concept mastery is important in studying physics (Hapsoro \& Susanto, 2012; Linuwih \& Sukwati, 2014; Owagbemi, 2018; Saregar, Diani, \& Kholid, 2017; Saregar, Latifah, \& Sari, 2016). However, students' concept mastery of physics is still lacking (Husein, Herayanti, \& Gunawan, 2015). Thus teachers need to emphasize the concept mastery of physics in their learning (Adhim \& Jatmiko, 2015; Iwuchukwu, Ineji \& Inyang, 2018; Lestari \& Rahayu, 2015). One of the materials of physics which requires a strong concept mastery is the material of temperature and heat (P, H, \& Wisodo, 2016; Rimadani, Parno, \& Diantoro, 2016).

Temperature and heat are the physics materials with the most misconception in the practice (P. P. Lestari \& Linuwih, 2014). Some students assume that temperature and heat are the same (K \& Komalasari, 2012). In the teaching of temperature and heat materials, some teachers experience constraints on how to embed the correct concept in students, in order to minimize misconception (Yolanda, Syuhendri, \& Andriani, 2016).

The proper understanding of the concept of science can be undertaken, one of them by using a variety of learning models (Hamzah \& Mohamad, 2012; Jiang \& McComas, 2015; Martin \& Ratna, 2015). Some learning models which can be applied in the learning of physics, among others: Project Based Learning (Munawaroh, Subali, \& Sopyan, 2012), Inquiry (Sugiarti, Susanto, \& Khanafiyah, 2015), Discovery Learning (Syafi'i, Handayani, \& Khanafiyah , 2014), Problem Based Learning (PBL) (Mayasari \& Adawiyah, 2015) and ARIAS Learning Model (Wibowo \& Joko, 2014).

The learning models of ARIAS and PBL have been proven to improve concept mastery (Fauzan, Gani, \& Syukri, 2017; Kadek, Kusuma, Riastini, \& Pudjawan, 2017; Leliavia, Muhdhar, \& Suwono, 2017). In accordance with the previous study, ARIAS learning model can improve the concept mastery (Andriyani \& Soeprodjo, 2013; Hermawati, Lisa, \& Elvia, 2014; Kadek et al., 2017; Kriana, Waluyo, \& Concern, 2014). ARIAS learning model is the result of the development of ARCS model by Keller and Kopp in the effort to design learning which can influence the achievement motivation and learning outcomes (Rahayu, Waluyo, \& Sugiman, 2014).

In addition to ARIAS learning model, Problem Based Learning (PBL) model can also improve the concept mastery (Alan \& Afriansyah, 2017; Fauzan et al., 2017; Handika \& Wangid, 2013; Mayasari \& Adawiyah, 2015). Problem Based Learning is an innovative learning model which can optimize students' thinking ability, through systematic group or teamwork processes (Fauzan et al., 2017, Kim, 2016; Yoon, Woo, Treagust, \& Chandrasegaran, 2014).

The study attempts to report the results of research related to which learning model is more effectively used to improve the concept mastery of temperature and heat materials on high school students, between the learning model of ARIAS with Problem Based Learning (PBL). The implementation of both ARIAS and PBL models are learning models which directly expose the students to the reality of everyday life so that the concept mastery of students can be trained.

\section{RESEARCH METHODS}

The study was conducted at Senior High School YP Unila of Bandar Lampung in the even semester of academic year 2015/2016. The research subjects consist of two classes, i.e., X MIPA 2 as the experimental class I (ARIAS) and X MIPA 4 as the experimental class II (Problem Based Learning). The materials learned in the study are temperature and heat. The sampling in the study used Cluster Random Sampling technique.

The study uses Quasi-Experiment Design method. The Quasi-experiment design used is Nonequivalent Control Group Design. The research variables used is the independent variable in the form of ARIAS learning model $\left(X_{1}\right)$ and Problem Based Learning model $\left(\mathrm{X}_{2}\right)$, while the dependent variable is the Concept Mastery of Temperature and Heat $(Y)$.

The technique of data collection in the study is in the form of test. The form of the written test questions used as pretest and posttest is plural choice. The test is used to obtain the data of students' concept mastery as the answer to the problems formulated. Before the test instrument is used, validity test, reliability test, distinguishing power, 
difficulty level and distractor were done. The data analysis used in the study is a prerequisite analysis test in the form of normality test and homogeneity test.

The statistical analysis used to determine whether there is a difference between learning model of ARIAS and $\mathrm{PBL}$, tested the hypothesis using t-test, and to find out the effectiveness of learning model on concept mastery using Effect Size test, some of the following formula can be used (Hake, 2002).

$$
d=\left(M_{A}-M_{B}\right) /\left[\left(S d_{A}^{2}+S d_{B}^{2}\right) / 2\right]^{1 / 2}
$$

with:

$d=$ Effect Size,

$M_{A}=$ the average Gain of experimental class I,

$M_{B}=$ the average Gain of experimental class II,

$S d_{A}^{2}=$ the standard deviation of experimental class I,

$S d_{B}^{2}=$ the standard deviation of experimental class II.

The following formula can also be used (Nurhayati, Fadilah, \& Mutmainnah, 2014).

$$
E S=\frac{\bar{X}_{x}-\bar{X}_{y}}{S D_{y}}
$$

with:

$E S=$ Effect Size,

$\bar{X}_{x}=$ the average of experimental class I,

$\bar{X}_{y}=$ the average of experimental class II,

$S D_{y}=$ the standard deviation of experimental class II.

The following formula can also be used (Ari Sumirat, 2014).

with:

$$
E S=t \sqrt{\frac{1}{N_{1}}+\frac{1}{N_{2}}}
$$

$t=\mathrm{t}$-test score,

$N_{1}=$ the number of experimental class I students,

$N_{2}=$ the number of experimental class II students.

With the criteria of effect size as follows:

$$
\begin{array}{ll}
E S<0.2 & \text { Low } \\
0.2 \leq E S \leq 0.8 & \text { Medium } \\
E S>0.8 & \text { High }
\end{array}
$$

The study uses the formula of Hake to determine the score of Effect Size.

\section{RESULTS AND DISCUSSION}

\section{Research Results}

Prior to hypothesis testing, normality and homogeneity tests should be done with significance level $(\alpha)=0.05$.

The increase of the average mastery of experimental group I in Table $\mathbf{1}$ can be seen from the average scores of pretest and posttest of 46.5 and 76.25. Whereas the increase of the average mastery of experimental group II in Table 2 can be seen from the average scores of pretest and posttest of 50.62 and 73.12. Thus, it can be concluded that the learning of experimental group I which uses ARIAS learning model is better than experimental group II which uses the PBL model. 
Table 1. The recapitulation of pretest and posttest scores in the experimental class I

\begin{tabular}{ccc}
\hline Pretest & Description & Posttest \\
\hline 65 & Highest Score & 90 \\
\hline 30 & Lowest Score & 55 \\
\hline 1860 & The total score of experimental class I & 3060 \\
\hline 46.50 & Average score & 76.50 \\
\hline
\end{tabular}

Table 2. The recapitulation of pretest and posttest scores in the experimental class II

\begin{tabular}{ccc}
\hline Pretest & Description & Posttest \\
\hline 65 & Highest Score & 90 \\
\hline 30 & Lowest Score & 55 \\
\hline 1860 & Total score of experimental class II & 3060 \\
\hline 46.50 & Average score & 76.50 \\
\hline
\end{tabular}

Table 3. The Recapitulation of Normality Test Results of experimental class I

\begin{tabular}{cccc}
\hline Test results & $\mathbf{L}_{\mathbf{h}}$ & $\mathbf{L}_{\text {table }}$ & Conclusion \\
\hline Pre-post & 0.11 & 0.14 & Normal \\
\cline { 2 - 4 } ex. I & 0.09 & 0.14 & Normal \\
\hline Pre-post & 0.12 & 0.14 & Normal \\
ex. II & 0.13 & 0.14 & Normal \\
\hline
\end{tabular}

Table 4. The Recapitulation of Homogeneity Test Results

\begin{tabular}{cccc}
\hline Test results & $\mathbf{F}_{\text {calculate }}$ & $\mathbf{F}_{\text {table }}$ & Conclusion \\
\hline Pretest & 1.16 & 1.69 & Homogeneous \\
\hline Posttest & 1.60 & 1.69 & Homogeneous \\
\hline
\end{tabular}

Table 5. Hypothesis Test

\begin{tabular}{cccc}
\hline Instrument & $\mathbf{T}_{\text {calculate }}$ & $\mathbf{T}_{\text {table }}$ & Description \\
\hline$N$-Gain & 2.03 & 1.99 & $\mathrm{~T}_{\text {calculate }}>\mathrm{T}_{\text {table }}=\mathrm{H}_{0}$ is Rejected \\
\hline
\end{tabular}

Table 6. The Effect Size data of experimental class I and experimental class II

\begin{tabular}{cccc}
\hline Mean of Ex. I & Mean of Ex. II & Effect Size & Criteria \\
\hline 30 & 24 & 0.45 & Medium
\end{tabular}

Based on the Table 3 of experimental class $I_{\text {, }} \mathrm{L}_{\text {calculate }}=0.11$ is obtained, which is the largest value with the number of samples $=40$ and significant level $a=0.05$, then $\mathrm{L}_{\text {table }}=0.14$ also obtained. Based on the calculation results, it can be seen that at a significant level of $0.05, \mathrm{~L}_{\text {calculate }}<\mathrm{L}_{\text {table, }}$ which means hypothesis $\mathrm{H}_{0}$ is accepted. Thus, it can be concluded that the sample came from a normally distributed population. From the results of normality test for experimental class II, $\mathrm{L}_{\text {calculate }}=0.12$ is obtained, which is is the largest value with the number of samples = 40 and significant level $\alpha=0.05$, then $\mathrm{L}_{\text {table }}=0.14$ also obtained. Based on the calculation results, it can be seen that at a significant level of $0.05, \mathrm{~L}_{\text {calculate }}<\mathrm{L}_{\text {table, }}$ which means hypothesis $\mathrm{H}_{0}$ is accepted. Thus, it can be concluded that the sample came from a normally distributed population.

Based on Table 4, the pretest results of the experimental class I and the experimental class II are $\mathrm{F}_{\text {calculate }}=1.16$ and $\mathrm{F}_{\text {Table }}=1.69$. Whereas the posttest results of the experimental class I and the experimental class II are $\mathrm{F}_{\text {calculate }}=$ 1.60 and the same $F_{\text {Table }}=1.69$. The table shows that $F_{\text {calculate }}<F_{\text {table. }}$. It indicates that there is no significant difference, which means that the data are homogeneous or the same.

Based on Table 5, the scores of $t_{\text {calculate }}>t_{\text {table }}(2.03>1.99)$, which means $\mathrm{H}_{0}$ is rejected. Thus, it can be concluded that there are differences in the learning model of ARIAS and Problem Based Learning (PBL) on the concept mastery of temperature and heat in the students of class X MIPA in Senior High School YP Unila of Bandar Lampung.

Based on Table 6, it is known that the score of Effect Size $=0.45$ with medium criteria.

\section{DISCUSSION}

Students' concept mastery can be seen from the pretest and posttest scores. Pretest is given at the beginning of class before the temperature and heat materials are taught. From the data of study results in the experimental class I, the lowest score of 30 and the highest score of 65 with the average score of 47.5 are obtained. Whereas in the experimental class II, the lowest score of 35 and the highest score of 70 with the average score of 50.62 are obtained. Judging from the pretest average scores of both experimental class I and experimental class II, the students' concept 
mastery of temperature and heat materials is still low, and both classes have the same initial capability of temperature and heat materials.

The learning given to the experimental group I and the experimental group II is adapted to the steps of both learning models which will be applied, i.e., the learning model of ARIAS and Problem Based Learning (PBL).

Students' learning using ARIAS learning model has better concept mastery, because in the process students feel more interested and motivated. Moreover, with ARIAS learning model, students can observe their own experiences, both in the past and in the future, around their environment and understand it.

Students' motivation develops into curiosity, as well as self-confidence and learning interest in improving the concept mastery of temperature and heat materials they learn. With this model of learning, learning becomes more interesting, fun and improves students' mastery. This is in accordance with the research results of Lastri et al. (Lastri, Arif, \& Nurhidayati, 2015).

The results of pretest and posttest data analysis in both groups indicate that students' concept mastery is homogenous. Thus, in testing whether there is difference in concept mastery between the experimental group I and experimental group II, the statistical test used is parametric test, which is t-test. The use of ARIAS learning model affects students' concept mastery. The result of t-test with $5 \%$ significant level shows $t_{\text {calculate }}=2.03$ and $t_{\text {table }}=1.99$. It means $t_{\text {calculate }}>t_{\text {table, }}$ thus, it can be concluded that there is difference in the use of physics learning model of ARIAS with Problem-based learning (PBL) on students' concept mastery.

From the calculation result with the formula of Effect Size, score of 0.45 is obtained with medium category. Because the effect size score is positive, the experimental group I is more effective than the experimental group II. It indicates that the use of ARIAS learning model is more effective in improving the students' concept mastery on temperature and heat materials, than the use of Problem Based Learning (PBL) model.

The concept mastery of experimental group I with ARIAS learning model is higher than in experimental group II with PBL model. This is in accordance with the study (Lastri et al., 2015; Purnamasari \& Nurfitri, 2013) which suggests that ARIAS learning model can improve students' learning outcomes. Other results (Khoiriyah \& Rusimamto, 2016) suggest that the use of ethnomatematics-based ARIAS learning model can improve the capability of problem solving with the process skills of students. The results of the study (Kriana et al., 2014) indicate that ARIAS learning model is effective in improving the activities and learning outcomes of students (Saminan, Hamid, \& Risha, 2017; Wardana \& Edoh, 2017).

Similarly, the results of the study (Rahayu et al., 2014) also indicate that mathematics learning model of ARIAS assisted with problem card is effective in mathematical communication ability of students. The difference with this study lies in the variables, which focus on students' concept mastery. This study is supported by previous study.

This study has some limitations, in which the implementation of learning using the learning model of ARIAS and PBL is not maximum. The presentation of learning by researchers has not been fully met as planned. Less optimum class control made the classroom atmosphere less conducive that the concentration of students is disrupted.

\section{CONCLUSIONS AND SUGGESTIONS}

\section{Conclusions}

1. There is a difference between the implementation of physics learning model of ARIAS and Problem Based Learning (PBL) on the concept mastery of temperature and heat in the students of class X MIPA in Senior High School YP Unila of Bandar Lampung of academic year 2015/2016.

2. The implementation of physics learning model of ARIAS is more effective than Problem Based Learning (PBL).

\section{Recommendation}

Based on the results of the study, it is recommended that educators should apply such learning models that have been adjusted to the learning material for optimum students' ability and competence. Other researchers can continue using ARIAS and PBL learning models in other physics materials. Nevertheless, they should first reanalyze to adjust the implementation, especially in terms of time allocation and supporting facilities including learning media and students' characteristics in the school in which the device is applied. 


\section{REFERENCES}

Adha Priyo Wibowo, R. (2014). Penerapan Model Pembelajaran Secara Langsung dengan Strategi ARIAS untuk Meningkatkan Hasil Belajar Siswa. Jurnal Pendidikan Teknik Elektro, 03(02).

Adhim, A. Y. (2015). Penerapan Model Pembelajaran Guided Discovery dengan Kegiatan Laboratorium Untuk meningkatkan Hasil Belajar Siswa Kelas X Pada Materi Suhu dan Kalor. Inovasi Pendidikan Fisika, 04(03).

Aina, J. K. (2015). Analysis of Integrated Science and Computer Science Students' Academic Performances in Physics in Colleges of Education, Nigeria. International Journal of Education and Practice, 3(1), 28-35. https:/ / doi.org/10.18488/journal.61/2015.3.1/61.1.28.35

Amida, N., Joko, \& Jekti. (2014). Penerapan Model Pembelajaran ARIAS Untuk Meningkatkan Aktivitas dan Hasil Belajar Biologi Siswa Kelas XI IPA 4 Man 1 Jember. Pancaran, 3(2).

Andriyani, W., \& Soeprodja. (2013). Peningkatan Keterampilan Berpikir Kritis Siswa dengan Penerapan Model Pembelajaran ARIAS. Jurnal Chemistry in Education, 2(2).

Anjariyah, D., \& Karlina, L. (2016). Pengaruh Modelpembelajaran Arias (Assurance, Relevance, Interest, Assessment, and Satisfaction) Berbantu Media Lingkungan Terhadap Minat Dan Hasil Belajar Matematika Siswa Smp Pada Materi Aritmetika Sosial. Prosiding Konferensi Nasional Penelitian Matematika dan Pembelajarannya (KNPMP I) Universitas Muhammadiyah Surakarta, 12 Mar. 2016.

Ari Sumirat, L. (2014). Efektifitas Strategi Pembelajaran Kooperatif Tipe Think-Talk-Write (TTW) Terhadap Kemampuan Komunikasi Dan Disposisi Matematis Siswa. Jurnal Pendidikan dan Keguruan, 1(2).

Arif, et al. (2013). Pengaruh Model Pembelajaran CTL terhadap Hasil Belajar Biologi Siswa Kelas VII SMPN I Padang. Prosiding Semirata FMIPA Universitas Lampung.

Basuki, B., Doyan, A., \& Harjono, A. (2015) Pengembangan Alat Peraga Kotak Energi Model Inkuiri Terbimbing (APKEMIT) Sebagai Penunjang Pembelajaran Fisika SMA Pada Materi Suhu dan Kalor. Jurnal Penelitian Pendidikan IPA, 1(2).

Becerra-Labra, C., Gras-Martí, A, \& Torregrosa, J. M. (2012) Effects of a Problem-based Structure of Physics Contents on Conceptual Learning and the Ability to Solve Problems. International Journal of Science Education, 34(8). https:// doi.org/10.1080/09500693.2011.619210

Cao, Y., Kurbanova, A. T., \& Salikhova, N. R. (2017). Development of Classification Thinking in Future Teachers: Technologies of Reflective Discussion. EURASIA Journal of Mathematics, Science and Technology Education, 13(6), 1865-1879. https:/ / doi.org/10.12973/eurasia.2017.01205a - 1

Chandra, E. (2011). Efektivitas Media Pembelajaran dalam Pembelajaran Biologi (Meta Analisis Terhadap Penelitian Eksperimen dalam Pembelajaran Biologi). Holistik, 12(01), 103-128.

Departemen Pendidikan Nasional (2008). UU RI NO.20 Tahun 2003 Sistem Pendidikan Nasional. Jakarta: Sinar Grafika.

Dewa Ayu, I., et al. (2014). Pengaruh Model Pembelajaran ARIAS dengan Setting Group Investigation Terhadap motivasi dan Hasil Belajar Geografi Siswa kelas XI IPS SMA Negeri 2 Kuta Kabupatan Badung. e-Jurnal program Pascasarjana Universitas Pendidikan Ganesha, 5.

Fakhruriza, O., \& Ika. (Oct. 2015). Keefektifan Model Pembelajaran Relating, Experiencing, Applying, Cooperating, Transfering (REACT) Untuk Meningkatkan hasil Belajar Siswa SMP Pada Materi Kalor. JRKPF UAD, 2(2).

Gambari, A.I., Shittu A.T., \& Taiwo, O.A. (2016). Enhancing Students' Understandingof Algebra Concepts through Cooperative Computer Instruction. Pedagogical Research, 1(2), 55. https:/ / doi.org/10.20897/lectito.201655

Garaeva, A. K., \& Ahmetzyanov, I. G. (2018). Awareness of Historical Background as One of the Factors of Better Language Acquisition. International Journal of English Language and Literature Studies, 7(1), 15-21.

Gazzola, M. P., Otero, M. R., \& Llanos, V. C. (2015). Teaching of Mathematics and Physics in Secondary School through Research and Study Paths. International Journal of Education and Practice, 3(2), 85-89. https:/ / doi.org/10.18488/journal.61/2015.3.2/61.2.85.89

Gok, T., \& Silay, I. (2008). Effect of Problem Solving Strategy teaching on the Problem-Solving Attitude of Cooperating Learning Group in Physics education. Journal Of theory and practice in education, 4(2), 253-256.

Gorev, P. M., Masalimova, A. R., Mukhametzyanova, F. Sh., \& Makarova, E. V. (2017). Developing Creativity of Schoolchildren through the Course "Developmental Mathematics". EURASIA Journal of Mathematics, Science and Technology Education, 13(6), 1799-1815. https:/ / doi.org/10.12973/ eurasia.2017.00698a

Hake, R. R. (2002). Relationship of Individual Student Normalized Learning Gains in Mechanics with Gender, High School Physics and Pretest Scores on Mathematics and Spatial Visualization. Physics education research conference, 1(1), 30-45. 
Handika, I., \& Nur Wangid, M. (2013). Pengaruh pembelajaran Berbasis Masalah Terhadap Penguasaan konsep dan Keterampilan proses Sains Siswa Kelas V. Jurnal Prima Edukasia, 1(1). https:// doi.org/10.21831/jpe.v1i1.2320

Hanson, R. (2016). Ghanaian Teacher Trainees' Conceptual Understanding of Stoichiometry. Journal of Education and e-Learning Research, 3(1), 1-8. https:/ / doi.org/10.20448/journal.509/2016.3.1/509.1.1.8

Hanzah, Y., \& Sufianto. (2014). Pembelajaran Fisika Menggunakan Better Teaching and Learning Berketerampilan Proses Untuk Meningkatkan Aktivitas Belajar Siswa SMP. Unnes Physics Education Journal, 2(3).

Hapsoro, C. A., \& Susanto, H. (2012). Penerapan Pembelajaran Problem Based Instruction Berbantuan Alat Peraga Pada Materi Cahaya Di SMP. Jurnal Pendidikan Fisika Indonesia, 7, 28-32.

Hermawati, Lisa, Sukirman \& Elvia. (2014). Upaya Meningkatkan Keaktifan Belajar dan Hasil belajar Akuntansi dengan Strategi Pembelajaran ARIAS terintegrasi dengan Ppembelajaran Aktif Learning Tournament pada siswa kelas X AK 2 SMK Surakarta. Jupe UNS, 2(3).

Husein, S., Herayanti, L., \& Gunawan, G. (2015). Pengaruh Penggunaan Multimedia Interaktif terhadap Penguasaan Konsep dan keterampilan Berpikir kritis Siswa pada materi Suhu dan kalor. Jurnal Pendidikan Fisika dan Teknologi, 1(3).

Iwuchukwu, G. C., Ineji, P. U., \& Inyang, E. (2018). Language, Communication, Poverty Eradication and the Fadama Projects in Nigeria. Global Journal of Social Sciences Studies, 4(1), 1-12. https:/ / doi.org/10.20448/807.4.1.1.12

Jayakumar, R. (2016). Opinion of the University Teachers towards Educational Television Programmes. American Journal of Education and Learning, 1(1), 45-52.

Jiang, F., \& Mc Comas, W. F. (2015). The Effects of Inquiry Teaching on student Science Achievement and Attitudes: Evidence from Propensity Score Analysis of PISA Data. International Journal of Science Education, 37(3), 554576. https:// doi.org/10.1080/09500693.2014.1000426

Kalimullin, A. M., \& Utemov, V. V. (2017). Open Type Tasks as a Tool for Developing Creativity in Secondary School Students. Interchange, 48, 129-144. https:/ / doi.org/10.1007/s10780-016-9295-5

Ke, Z., Borakova, N. U., \& Valiullina, G. V. (2017). Peculiarities of Psychological Competence Formation of University Teachers in Inclusive Educational Environment. EURASIA Journal of Mathematics, Science and Technology Education, 13(8), 4701-4713. https:/ / doi.org/10.12973/eurasia.2017.00947a

Khoiriyah, N. (2016). Implementasi Model Pembelajaran ARIAS Untuk Meningkatkan Hasil Belajar Pada Kompetensi Dasar Macam-macam Rangkaian Flip-Flop Siswa Kelas X TEI di SMK Negeri 2 Bangkalan. Jurnal Pendidikan Teknik Elektro, 05(01).

Kim, M. (2016). Children's Reasoning as Collective Social Action through Problem Solving in Grade 2/3 Science Classrooms. International Journal of Science Education, 38(1). https:/ / doi.org/10.1080/09500693.2015.1125559

Kurihara, Y. (2016). Flipped Classroom: Effects on Education for the Case of Economics. Journal of Education and eLearning Research, 3(2), 65-71. https:/ / doi.org/10.20448/journal.509/2016.3.2/509.2.65.71

Kweka, K. H., \& Ndibalema, P. (2018). Constraints Hindering Adoption of ICT in Government Secondary Schools in Tanzania: The Case of Hanang District. International Journal of Educational Technology and Learning, 4(2), 46-57. https:/ / doi.org/10.20448/2003.42.46.57

Lastri, A., \& Nurhidayati. (2015). Efektivitas Model Pembelajaran ARIAS dalam meningkatkan motivasi dan hasil belajar Siswa Kelas X SMA Negeri 8 Purworejo TP 2014/2015. Radiasi, 7(2).

Lebdiana, R., Sulhadi \& Hindarto, N. (2015). Pengembangan Perangkat Pembelajaran Materi Suhu dan Kalor Berbasis POE (Predict-Observe-Explain) Untuk Meremediasi Miskonsepsi Siswa. Unnes Physics Education Journal, 4(2).

Lestari, P. P., \& Linuwih, S. (2014). Analisis Konsepsi dan Perubahan Konseptual Suhu dan Kalor Pada Siswa SMA Kelas Unggulan. Unnes Physics Educational Journal, 3(2).

Lestari, P., Rahayu, S., \& Hikmawati, H. (2015). Profil Miskonsepsi Siswa Kelas X SMKN 4 Mataram Pada Materi Pokok Suhu, Kalor, dan Perpindahan Kalor. Jurnal Pendidikan Fisika dan Teknologi, 1(3).

Linuwih, S, \& Sukwati. (2014). Efektivitas Model Pembelajaran AIR terhadap Pemahaman Siswa pada Konsep Energi Dalam. Jurnal Pendidikan Fisika Indonesia, 10(2).

Luneeva, O. L., \& Zakirova, V. G. (2017). Integration of Mathematical and Natural-Science Knowledge in School Students' Project-Based Activity. EURASIA Journal of Mathematics, Science and Technology Education, 13(7), 2821-2840. https:/ / doi.org/10.12973/eurasia.2017.00720a

Make, M., \& Yonas, A. (2018). Teachers Perception on the Use of Audiovisual Materials to Teach English Speaking Skill: Abba Pascal Girls School in Focus. International Journal of English Language and Literature Studies, 7(1), 1-6. https:/ / doi.org/10.18488/journal.23.2018.71.1.6 
Martin, \& Ermawaty, I. R. (2015). Pengaruh Pemberian Tes Berstruktur dalam Model Pembelajaran Problem Solving Terhadap Kemampuan Berpikir Sistematis Siswa di SMAN 72 Jakarta. OMEGA Jurnal Fisika dan Pendidikan Fisika, 1(2).

Mayasari, Ria, \& Rabiatul. (2015). Pengaruh Model Pembelajaran Berbasis Masalah Pada Pembelajaran Biologi Terhadap Hasil Belajar dan Keterampilan Berpikir Tingkat Tinggi di SMA. Jurnal Pendidikan Biologi Indonesia, 1(3).

Nor, M., et al. (2013). Motivasi Belajar Fisika Siswa Melalui Penerapan Pendekatan Arias Pada Siswa Kelas Viii Smp Negeri 4 Tambang. Prosiding Semirata FMIPA Universitas Lampung, 1(1).

Nurhayati, N., et al. (2014). Penerapan Metode Demonstrasi Berbantu Media Animasi Software Phet Terhadap Hasil Belajar Siswa Dalam Materi Listrik Dinamis Kelas X Madrasah Aliyah Negeri 1 Pontianak. Jurnal Pendidikan Fisika dan Aplikasinya (JPFA), 4(2). https:/ / doi.org/10.26740/jpfa.v4n2.p1-7

Owagbemi, G. O. (2018). Assessing the Relocation of Adekunle Ajasin University to Akokoland on Transportation System and Rural Development in Ondo State. Humanities and Social Sciences Letters, 6(2), 51-58. https:// doi.org/10.18488/journal.73.2018.62.51.58

Piyatissa, M. L. S., Johar, M. G. M., \& Tarofder, A. K. (2018). Multiple Representations in Dispelling Some Common Misunderstandings and Increasing the Clarity of Principles of Physics Taught at Secondary School Level. Asian Journal of Contemporary Education, 2(2), 122-135. https:/ / doi.org/10.18488/journal.137.2018.22.122.135

Purnamasari, N., et al. (2013). Meningkatkan Hasil Belajar Siswa dengan Model Pembelajaran ARIAS ( Assurence, Relevance, Interest, Assessment, and Satisfaction). Berkala Ilmiah Pendidikan Fisika, 1(1). https:/ / doi.org/10.20527/ bipf.v1i1.856

Purwanti, S., \& Manurung, S. (2015). Analisis Pengaruh Model Pembelajaran Problem Solving dan Sikap Ilmiah Terhadap Hasil Belajar Fisika. Jurnal Pendidikan Fisika, 4(1). https:/ / doi.org/10.22611/jpf.v4i1.2569

Qosim, S., et al. (2015). Pengaruh model PBM berbantuan video kartun terhadap hasil belajar fisika siswa kelas XI SMAN 1 Sikur. Jurnal Pijar MIPA, X(1).

Rahayu, E. A., Waluyo, S. B., \& Sugiman, S. (2014). Keefektifan Model ARIAS Berbantu Kartu Masalah Untuk Meningkatkan Kemampuan Komunikasi Matematis Siswa. Jurnal Kreano, 5(1).

Rosyidatul, et al. (2012). Penerapan Model Project Based Learning dan Kooeperatif untuk Membangun Empat Pilar Pembelajaran Siswa SMP. Unnes Physics Education Journal, 1(1).

Rusman. (2014). Model-model Pembelajaran, Pengembangan Profesionalisme Guru. Jakarta: RajaGrafindo.

Setyadi K, Eko. (2012). Miskonsepsi tentang Suhu dan Kalor Pada Siswa Kelas 1 di SMA Muhamadiyah Purworejo Jawa Tengah. Jurnal berkala Fisika Indonesia, $4(1 \& 2)$.

Setyorini, U., Sukiswo, S. E., \& Subali, B. (2011). Penerapan Model Problem Based Learning untuk Meningkatkan Kemampuan Berpikir Kritis Siswa SMP. Jurnal Pendidikan Fisika Indonesia, 7(1).

Suardani, N. N., Swasta, I. B. J., \& Widiyanti, N. L. P. M. (2014). Pengaruh Model Pembelajran Berbasis Masalah Terhadap Kemampuan Pemecahan Masalah dan Keterampilan Proses Sains Siswa. e-Jurnal Program Pascasarjana Universitas Pendidikan Ganesha Pendidikan IPA, 4(1).

Sugiarti, E., Susanto, H., \& Khanafiyah, S. (2015). Pengaruh Model Pembelajaran Inquiry berbasis Metode Pictorial Riddle Terhadap Kemampuan Berkomunikasi Ilmiah Siswa SMP. Unnes Physics Education Journal, 4(3).

Suryati, Masrukan, \& Wardono. (2013). Pengaruh Asesmen Kinerja Dalam Model Pembelajaran ARIAS terhadap Kemampuan Pemecahan Masalah. Unnes Journal of Mathematics Education, Vol 2(3).

Syafii, Handayani, \& Khanafiyah. (2014). Penerapan Question Based Discovery Learning Kegiatan Laboratorium Fisika Untuk meningkatkan Keterampilan Proses Sains. Unnes Physics Education Journal, 3(2).

Taale, K. D. (2013). Remediating some learning difficulties of L200 science education students of Modibbo Adama University of Technology in some physics concepts using multiple representations. International Journal of Education and Practice, 1(3), 26-43. https:/ / doi.org/10.18488/journal.61/2013.1.3/61.3.26.43

Thibaut, L., Ceuppens, S., De Loof, H., De Meester, J., Goovaerts, L., Struyf, A., Boeve-de Pauw, J., ..., Depaepe, F. (2018). Integrated STEM Education: A Systematic Review ofInstructional Practices in Secondary Education. European Journal of STEM Education, 3(1), 02. https://doi.org/10.20897/ejsteme/85525

Uno, H. B., \& Mohamad, N. (2012). Belajar dengan Pendekatan PAILKEM. Jakarta: Bumi Aksara.

Yanga, J. Y., \& Yenb, Y. C. (2016). College Students' Perspectives of E-Learning System Use in High Education. Asian Journal of Education and Training, 2(2), 53-62. https:/ / doi.org/10.20448/journal.522/2016.2.2/522.2.53.62 
Yoon, H., Woo, A. J., Treagust, D., \& Chandrasegaran, A. L. (2014). The Efficacy of Problem-based Learning in an Analytical Laboratory Course for Pre-service Chemistry Teachers. International Journal of Science Education, 36(1), 79-102. https:// doi.org/10.1080/09500693.2012.727041

Zunanda, M., \& Sinulingga, K. (2015). Pengaruh Model Pembelajaran Berbasis Masalah dan Kemampuan berpikir Kritis Terhadap Keterampilan Pemecahan Masalah Fisika Siswa SMK. Jurnal Pendidikan Fisika, 4(1). https:// doi.org/10.22611/jpf.v4i1.2570

\section{http://www.ejmste.com}

